\title{
Prevalence of Metabolic Syndrome in Primary Hyperparathyroidism
}

\section{Primer Hiperparatiroidili Hastalarda Metabolik Sendrom Sıklı̆ı}

\author{
Gökçen Tuğba Çevik, Sibel Güldiken*, Neslihan Soysal Atile*, Hüseyin Çelik*, \\ Mehmet Çelik*, Semra Aytürk*, Necdet Süt**, Ayşe Armağan Tuğrul* \\ Trakya University Faculty of Medicine, Department of Internal Medicine, Edirne, Turkey \\ *Trakya University Faculty of Medicine, Department of Endocrinology and Metabolism Diseases, Edirne, Turkey \\ **Trakya University Faculty of Medicine, Department of Biostatistics, Edirne, Turkey
}

\section{Abstract}

Aim: In this study, we aimed to evaluate the prevalence of metabolic syndrome (MetS), metabolic abnormalities and independent predictors of MetS in primary hyperparathyroidism and to contribute to long-term follow-up and management of these patients.

Methods: Seventy-eight non-pregnant patients aged 18 years and over without renal or hepatic failure and other systemic diseases, who were diagnosed with primary hyperparathyroidism, between January 2005 and December 2014 were included in the study.

Results: Sixty-two (79.5\%) subjects were female and 16 (20.5\%) were male. The mean age of the patients was $55.3 \pm 12.6$ years. Fifty eight patients were classified as symptomatic and 20 as asymptomatic. Thirtytwo patients (41\%) were found to have primary hyperparathyroidism in accordance with the modified National Cholesterol Education ProgramAdult Treatment Panel III criteria. The frequency of urinary tract stone disease was significantly higher in patients with hyperparathyroidism with MetS than in those with primary hyperparathyroidism without MetS $(p=0.018)$.

Conclusion: In our study, the prevalence of MetS in patients with primary hyperparathyroidism was found to be similar to that demonstrated in epidemiological studies performed in the general population of the same age. However, in these patients higher prevalence of hypertension, increased waist circumference, lipid disorders such as some syndrome abnormalities that may lead to the increased cardiovascular morbidity and mortality were observed.

Keywords: Primary hyperparathyroidism, metabolic syndrome, parathyroid hormon
Amaç: Çalışmamızda primer hiperparatiroidizm olgularında metabolik sendromun (MetS) sıklığının tespiti, metabolik sendrom parametrelerinin incelenmesi ve primer hiperparatiroidizmde MetS belirleyicilerinin tayini ile bu hastaların uzun dönem takibine ve yönetimine katkıda bulunmayı hedefledik.

Yöntemler: Kliniğimizde Ocak 2005 ile Aralık 2014 tarihleri arasında takip edilen, primer hiperparatioidizm olarak tanımlanan, 18 yaşını doldurmuş, gebe olmayan, böbrek ve karaciğer yetmezliği ve diğer sistemik hastalıkları olmayan 78 hasta çalışmaya dahil edildi.

Bulgular: Hastaların 62'si $(\% 79,5)$ kadın, 16'sı $(\% 20,5)$ erkek, K/E: 3,87, yaş ortalamaları 55,3 312,6 yıl (27-78) olarak saptandı. Hastalardan 58 tanesinin primer hiperparatiroidizme ait semptom taşıdığı, 20 tanesinin semptomatik olmadığı tespit edildi. Hastalar "National Cholesterol Education Program-Adult Treatment Panel III" metabolik sendrom tanı kriterlerine göre değerlendirildiğinde, 32 hastada (\%41) MetS tespit edildi. MetS'li primer hiperparatiroidi hastalarında üriner sisteme ait taş hastalığı sıklığı, MetS olmayanlara göre istatiksel olarak anlamlı düzeyde yüksek tespit edildi ( $p=0,018)$.

Sonuç: Çalışma grubumuzdaki primer hiperparatiroidizmli hastalarda metabolik sendrom sıklığının epidemiyolojik çalışmalardaki genel toplumun aynı yaş grubu bireylerindeki metabolik sendrom sıklığı ile benzer olduğu görüldü. Ancak bu hastalarda kardiyovasküler morbidite ve mortalite artışına neden olabilecek hipertansiyon, artmış bel çevresi, lipid profili bozukluğu gibi sendrom anormallikleri sıklıklarında artış olduğu saptandı.

Anahtar Sözcükler: Primer hiperparatiroidi, metabolik sendrom, paratiroid hormon

Address for Correspondence/Yazışma Adresi: Sibel Güldiken

Trakya University Faculty of Medicine, Department of Endocrinology and Metabolism Diseases, Edirne, Turkey E-mail: sibel71@hotmail.com

Received/Geliş Tarihi: 30 October 2016 Accepted/Kabul Tarihi: 18 December 2016

This study was presented at $37^{\text {th }}$ Turkey Endocrinology and Metabolism Diseases Congress as a poster.

- Copyright 2017 by The Medical Bulletin of University of Health Sciences Haseki Training and Research Hospital The Medical Bulletin of Haseki published by Galenos Yayinevi. ${ }^{8}$ Telif Hakkı 2017 Sağlık Bilimleri Üniversitesi Haseki Eğitim ve Araştırma Hastanesi Haseki Tıp Bülteni, Galenos Yayınevi tarafından basılmıştır. 


\section{Introduction}

Primary hyperparathyroidism (PHPT) is the third most common endocrine disease after diabetes and thyroid diseases. It is defined as a condition characterized by hypercalcemia, hypophosphatemia and increased 1,25-dihydroxycholecalciferol level secondary to autonomous and excessive parathormone (PTH) secretion by the parathyroid glands (1). Patients may have various findings such as recurrent nephrolithiasis, osteoporosis, peptic ulcer, mental changes and, more rarely, widespread bone resorption (2). However, widespread use of serum calcium measurement enabled to diagnose patients with no symptoms or minimal disease-related findings other than hypercalcemia and increased PTH levels (1). By early detection of the disease before the development of disease findings, patients may be followed-up without undergoing surgery and natural course of the disease may be observed. This condition attracted attention to the relationship between PHPT and metabolic disorders-cardiovascular changes that cause increased morbidity and mortality (1). Causes of increased morbidity and mortality in PHPT are not well defined. However, it is thought that well defined components of metabolic syndrome (MetS) such as glucose metabolism abnormalities, hypertriglyceridemia, hypertension, hyperuricemia and well-known outcomes of PHPT such as left ventricular hypertrophy and arterial intimal thickening cause this condition (3). In this study, we aimed to examine MetS parameters in patients with PHPT and determine the prevalence of MetS in order to contribute to long-term follow-up and management of these patients.

\section{Methods}

Seventy-eight patients older than 18 years who were non-pregnant, diagnosed with PHPT after exclusion of secondary and tertiary hyperparathyroidism, had no renal or hepatic failure and other systemic diseases, had no history of drug use affecting glucose metabolism within the last three months, without the diagnosis of diabetes mellitus and accepted to participate in the study, were enrolled. Our study was planned in accordance with the principles of the Helsinki Declaration and written informed consent was obtained from all patients. The study was approved by the presidential ethics committee of our hospital. Outpatient clinic follow-up files of all patients were examined and body length (measured in the upright position, on flat surface and by stadiometer), body weight (measured in the fasting state and with fine clothes), waist circumference (measured in the upright position, with fine clothes, in mid-expirium, from the middle of the last rib and spina iliaca anterior superior) and diastolic and systolic blood pressure values (highest level measured at least 1 hour after caffeine and tobacco consumption, after 5 minutes rest, in the upright position and from both arms) were recorded. Body mass index (BMI) was calculated as body mass $(\mathrm{kg})$ divided by the square of the body height (meter). Drugs received by the patients (antihypertensive, antihyperlipidemic, antidiabetic, etc.) were examined. Fasting blood glucose and fasting lipid profile [Highdensity lipoproteins (HDL) cholesterol, low-density lipoprotein (LDL) cholesterol, and triglyceride] values were recorded from the patients' files. Hyperparathyroidismrelated bone pathologies (osteoporosis, subperiosteal resorption in hand phalanges, salt and pepper sign on skull, bone cysts, etc.) and urinary system pathologies (nephrolithiasis, urolithiasis, nephrocalcinosis, etc.) were recorded. The diagnosis of diabetes mellitus was made according to the American Diabetes Association criteria (4), while the World Health Organization criteria (5) were used for hypertension diagnosis. History of cardiovascular diseases, such as coronary artery disease, congestive heart failure and peripheral artery disease, was evaluated from the records or history taken from the subjects.

Seventy-eight patients with PHPT were assessed for the presence of stone disease, hyperparathyroidism bone disease, life-threatening hypercalcemia, nausea-vomiting secondary to hypercalcemia and hyperparathyroidismrelated neuromuscular disease findings; the patients with existing findings were accepted to be symptomatic, while the patients with no findings were classified as asymptomatic PHPT. In the same patient group, according to the National Cholesterol Education Program Adult Treatment Panel III (NCEP-ATP III) MetS diagnostic criteria (6); abdominal obesity (waist circumference: $>102 \mathrm{~cm}$ in males, $>88 \mathrm{~cm}$ in females) hypertriglyceridemia $(\geq 150$ $\mathrm{mg} / \mathrm{dL}$ or patients receiving antihyperlipidemic treatment) low HDL cholesterol ( $<40 \mathrm{mg} / \mathrm{dL}$ in males, $<50 \mathrm{mg} / \mathrm{dL}$ in females) hypertension (blood pressure $\geq 130 / 85 \mathrm{mmHg}$ or patients receiving antihypertensive drugs) hyperglycemia (fasting blood glucose $\geq 110 \mathrm{mg} / \mathrm{dL}$ or patients receiving anti-diabetic treatment or patients with the diagnosis of type 2 diabetes) were evaluated and patients having three or more of these were accepted to have MetS. Ethics committee approval was received for this study from the Ethics Committee of University (Approval Date: 27/03/2013 Approval Number: 07/01).

\section{Statistical Analysis}

Data were analysed using IBM SPSS Statistics, version 20.0 (SPSS Inc., Chicago, IL, USA). Descriptive statistical methods (mean, standard deviation) were used to evaluate study data. The one sample Kolmogorov-Smirnov test was used to determine whether the data were normally distributed. In the comparison of quantitative data, t-test was used in independent groups for the comparison of two 
groups in terms of normally distributed parameters. When the lowest expected value of the cells was $<5$, Fisher's exact test was used for the comparison of categorical variables, while Yates correction test was used when any of observed frequencies of the cells was between 5 and 25. The effects of age, gender, waist circumference, $\mathrm{BMI}$, fasting blood glucose level, HDL cholesterol level, triglyceride level, arterial blood pressure, concomitant diabetes mellitus, hypertension, metabolic bone disease, cardiovascular disease and nephrolithiasis variables on the presence of MetS were investigated by backward stepwise logistic regression model. A p value of less than 0.05 was considered statistically significant.

\section{Results}

Of the 78 patients with PHPT, 62 (79.5\%) were female and $16(20.5 \%)$ were male and the mean age was $55.3 \pm 12.6(27-78)$ years.

Anthropometric, clinical and laboratory features of the patients with PHPT were evaluated (Table 1). In patients

\begin{tabular}{|c|c|c|c|}
\hline & PHPT+MetS & PHPT-MetS & $\mathrm{p}$ \\
\hline Age (years) & $59.5 \pm 11.98$ & $52.3 \pm 12.35$ & 0.013 \\
\hline Gender (female/male) & $29 / 3$ & $33 / 13$ & 0.081 \\
\hline $\begin{array}{l}\text { Waist circumference } \\
(\mathrm{cm})\end{array}$ & $100.6 \pm 8.75$ & $94.6 \pm 9.08$ & 0.005 \\
\hline $\mathrm{BMI}\left(\mathrm{kg} / \mathrm{m}^{2}\right)$ & $30.7 \pm 3.50$ & $28.5 \pm 3.80$ & 0.012 \\
\hline $\begin{array}{l}\text { Systolic blood } \\
\text { pressure }(\mathrm{mmHg})\end{array}$ & $142.9 \pm 11.80$ & $125.9 \pm 18.90$ & $<0.001$ \\
\hline $\begin{array}{l}\text { Diastolic blood } \\
\text { pressure }(\mathrm{mmHg})\end{array}$ & $87.4 \pm 8.90$ & $78.6 \pm 9.30$ & $<0.001$ \\
\hline $\begin{array}{l}\text { Fasting blood } \\
\text { glucose (mg/dL) }\end{array}$ & $107.0 \pm 23.72$ & $97.5 \pm 8.80$ & 0.037 \\
\hline $\begin{array}{l}\text { HDL-cholesterol } \\
(\mathrm{mg} / \mathrm{dL})\end{array}$ & $46.2 \pm 9.23$ & $52.0 \pm 10.44$ & 0.014 \\
\hline $\begin{array}{l}\text { LDL-cholesterol } \\
(\mathrm{mg} / \mathrm{dL})\end{array}$ & $129.5 \pm 31.14$ & $113.1 \pm 20.49$ & 0.005 \\
\hline Triglyceride $(\mathrm{mg} / \mathrm{dL})$ & $142.9 \pm 68.37$ & $91.2 \pm 28.22$ & $<0.001$ \\
\hline $\begin{array}{l}\text { Urinary stone } \\
\text { disease }(n, \%)\end{array}$ & $16(50.0 \%)$ & $10(21.7 \%)$ & 0.018 \\
\hline $\begin{array}{l}\text { Hypertension } \\
\text { (number, \%) }\end{array}$ & $27(84.4 \%)$ & $10(21.7 \%)$ & $<0.001$ \\
\hline $\begin{array}{l}\text { Diabetes mellitus } \\
(n, \%)\end{array}$ & $7(21.9 \%)$ & $1(2.2 \%)$ & 0.007 \\
\hline $\begin{array}{l}\text { Cardiovascular } \\
\text { disease }(n, \%)\end{array}$ & $5(15.6 \%)$ & $1(2.2 \%)$ & 0.040 \\
\hline \multicolumn{4}{|c|}{$\begin{array}{l}\text { PHPT: Primary hyperparathyroidism, MetS: Metabolic syndrome, BMI: Body } \\
\text { mass index, HDL: High density lipoprotein, LDL: Low density lipoprotein, } \\
\text { n: Number }\end{array}$} \\
\hline
\end{tabular}

with MetS and PHPT, the mean age $(p=0.013)$, the mean BMI value $(p=0.012)$, the mean fasting blood glucose level $(p=0.037)$, the prevalence of concomitant urinary stone disease $(p=0.018)$ and cardiovascular disease $(p=0.040)$ were found to be significantly higher when compared to PHPT patients with no MetS. It was observed that the mean HDL cholesterol level in MetS group was significantly lower than in the group without MetS $(p=0.014)$. The mean waist circumference $(p=0.005)$, the mean systolic $(p<0.001)$ and diastolic $(p<0.001)$ blood pressure values, the mean LDL cholesterol $(p=0.005)$ and triglyceride $(p<0.001)$ levels and the prevalence of concomitant hypertension $(p<0.001)$ and diabetes mellitus $(p=0.007)$ were significantly higher in MetS group than in the group with no MetS.

In the assessment of all 78 patients with PHPT in terms of five abnormalities according to the NCEP-ATP III MetS diagnostic criteria, it was seen that nine patients (11.5\%) had no abnormality, 37 patients (47.5\%) had one or two abnormalities but no MetS, and 32 patients (41.0\%) had three or more abnormalities (Table 2). Among these subjects, 32 patients (41.0\%) with three or more metabolic abnormalities were accepted to have MetS. Each patient in the same study group was individually evaluated for the presence of metabolic abnormalities. The most common abnormality was found to be increased waist circumference $(70.5 \%$ of the patients); elevated blood pressure or antihypertensive treatment (51.2\%) and low HDL cholesterol level (42.3\%) are being the second and third, respectively. Hypertriglyceridemia or antihyperlipidemic treatment (15.3\%) and high fasting blood glucose or anti-diabetic treatment were the rarest metabolic abnormalities observed among the patients. In the evaluation of 32 patients with PHPT and MetS in terms of the same metabolic abnormalities, it was detected that all subjects $(100 \%)$ had increased waist circumference, $28(87.5 \%)$ had elevated blood pressure or been using

Table 2. Distribution of the subjects with primary hyperparathyroidism according to the number of metabolic syndrome diagnostic criteria

\begin{tabular}{|l|l|l|}
\hline $\begin{array}{l}\text { Number of abnormal } \\
\text { metabolic syndrome criteria }\end{array}$ & Number of subjects & Prevalence \\
\hline 0 & 9 & $11.5 \%$ \\
\hline 1 & 24 & $30.8 \%$ \\
\hline 2 & 13 & $16.7 \%$ \\
\hline 3 & 23 & $29.5 \%$ \\
\hline 4 & 7 & $9.0 \%$ \\
\hline 5 & 2 & $2.5 \%$ \\
\hline Total & 78 & $100 \%$ \\
\hline
\end{tabular}


antihypertensive medication, 25 (78.1\%) had low HDL cholesterol level, 12 (37.5\%) had hypertriglyceridemia or been using antihyperlipidemic treatment and 10 subjects $(31.5 \%)$ had high fasting blood glucose level or been using anti-diabetic treatment (Table 3).

In the evaluation of triple metabolic abnormality combinations detected in patients with MetS and PHPT; the most common combination was increased waist circumference, low HDL cholesterol and elevated blood pressure or antihypertensive drug use (65.6\%), while the second one was increased waist circumference, elevated blood pressure or antihypertensive medication use and elevated triglyceride level or antihyperlipidemic treatment (28.1\%).

MetS was detected in 7 (35\%) of 20 asymptomatic and $25(43.1 \%)$ of 58 symptomatic patients with PHPT. No significant difference was detected between the groups in terms of the prevalence of MetS.

In logistic regression model evaluating independent variables which indicate MetS in patients with PHPT (Table 4); variables, such as age, gender, waist circumference, BMI, fasting blood glucose level, HDL cholesterol level, triglyceride level, arterial blood pressure value, concomitant presence of diabetes mellitus, hypertension, metabolic bone disease, cardiovascular disease and nephrolithiasis were evaluated in backward stepwise logistic regression model and fasting blood glucose, arterial blood pressure and triglyceride level were found to be significant. It was found that fasting blood glucose $\geq 110 \mathrm{mg} / \mathrm{dL}$ increases the risk of MetS 34.7 time $s(p=0.003)$, triglyceride level $\geq 150 \mathrm{mg} / \mathrm{dL}$ increases the risk of MetS 48.7 times $(p=0.003)$, while arterial blood pressure $<130 / 85 \mathrm{mmHg}$ plays a protective role in MetS, in other words, a blood

\begin{tabular}{|c|c|c|c|}
\hline $\begin{array}{l}\text { Metabolic syndrome } \\
\text { abnormality }\end{array}$ & $\begin{array}{l}\text { All patients } \\
\mathrm{n}(\%)\end{array}$ & $\begin{array}{l}\text { MetS + } \\
\mathrm{n}(\%)\end{array}$ & $\begin{array}{l}\text { MetS - } \\
\text { n (\%) }\end{array}$ \\
\hline $\begin{array}{l}\text { Increased waist } \\
\text { circumference }\end{array}$ & 55 (70.5\%) & $32(100.0 \%)$ & $23(50.0 \%)$ \\
\hline $\begin{array}{l}\text { Hypertriglyceridemia or } \\
\text { Antilipidemic treatment }\end{array}$ & $12(15.3 \%)$ & $12(37.5 \%)$ & 0 \\
\hline $\begin{array}{l}\text { Low } \\
\text { HDL-cholesterol }\end{array}$ & $33(42.3 \%)$ & $25(78.1 \%)$ & $8(17.3 \%)$ \\
\hline $\begin{array}{l}\text { High blood pressure } \\
\text { or antihypertensive } \\
\text { treatment }\end{array}$ & $40(51.2 \%)$ & $28(87.5 \%)$ & $12(26.0 \%)$ \\
\hline $\begin{array}{l}\text { High fasting blood } \\
\text { glucose or antidiabetic } \\
\text { treatment }\end{array}$ & $12(15.3 \%)$ & $10(31.5 \%)$ & $2(4.3 \%)$ \\
\hline
\end{tabular}

pressure value of $\geq 130 / 85 \mathrm{mmHg}$ increases the risk of MetS $34.6(1 / 0.026=34.6)$ times.

\section{Discussion}

In our study, we found that the mean age of patients with PHPT and MetS was significantly higher than that of patients with PHPT without MetS $(p=0.013)$. This finding is consistent with the finding of MetS prevalence studies conducted on Turkish population suggesting that the prevalence of MetS increases with increasing age (7). In addition, the mean LDL cholesterol level was significantly higher in MetS group when compared with the group without MetS $(p=0.005)$. This finding suggests that although it is not one of the diagnostic criteria of MetS, increased LDL cholesterol which plays an important role in the pathogenesis of atherosclerosis (8) should be carefully evaluated in patients with PHPT, especially in those with MetS.

In our study, 32 of 78 patients with PHPT (41\%) were found to have MetS, while in a study by Delfini et al. (9) conducted in 2007, 67 patients who were newlydiagnosed with PHPT were enrolled and the prevalence of MetS, according to NCEP-ATP III MetS criteria was found to be $29.8 \%$ and in a controlled study conducted by Luboshitzky et al. (10) in 2009. The prevalence of MetS diagnosed according to the American Heart Association MetS criteria was detected as $36 \%$ and $14.4 \%$ in patients with PHPT and control groups, respectively. The prevalence of MetS diagnosed according to NCEP ATP III criteria was $42 \%$ in a Mexican study which involved adults older than 20 years, while another Mexican study conducted by Mendoza-Zubieta et al. (3) in 2009 involved 60 patients who were diagnosed with PHPT between 2006 and 2009 and scheduled for parathyroidectomy, 60\% of whom were found to have MetS according to pre-operative NCEP ATP III criteria (11). In a study by Tassone et al. (1), 154 patients with PHPT were evaluated in 2012 in Italy and the prevalence of MetS according to the NCEP-ATP III criteria was found to be $22.1 \%$ among these patients. This finding was similar to the prevalence of MetS in Italian population (19.2\%). In the same study, all patients were individually evaluated for metabolic abnormalities, which showed that the most common abnormality was high blood pressure level (81.2\%); low HDL cholesterol level $(31.8 \%)$ was the second most common and the rarest abnormality was high fasting blood glucose level detected in $13.0 \%$ of the subjects. It was reported that $67.6 \%$ of these patients had at least one metabolic abnormality independent of the presence of MetS, while only $10.4 \%$ had no abnormality. When compared with the study by Tassone et al. (1), the rate of patients detected to have MetS was higher in our study. This might be caused by the 
fact that the prevalence of MetS in Turkey is higher than in Italy. In studies performed to determine the prevalence of MetS in Turkey, the results varied between 30\% and $50 \%$, depending on the age and the methods used (7). This shows that the prevalence of MetS found in our study was similar to that in age-matched patients of general population involved in the studies. In the evaluation of triple metabolic abnormality combinations detected in 32 patients with MetS; the most common combination was increased waist circumference, low HDL cholesterol and elevated blood pressure or antihypertensive drug use $(65.6 \%, 21$ patients), while the second one was increased waist circumference, elevated blood pressure or antihypertensive medication use and elevated triglyceride level or antihyperlipidemic treatment (28.1\%, 9 patients), which shows that patients presenting with PHPT should be evaluated especially for waist circumference, arterial blood pressure and lipid profiles.

In the study by Tassone et al. (1), the prevalence of MetS in patients with asymptomatic PHPT was found to be significantly higher than that in symptomatic subjects (30.2\%, 16.5\%, p<0.045). However, Tassone et al. (1) suggested that this was caused by significantly higher age of the patients with asymptomatic PHPT included in their study group when compared to symptomatic group $(p<0.008)$. In a study by Procopio et al. (8), 68 patients with PHPT and a control group were evaluated in 2013 with regard to the NCEP-ATP III MetS criteria and the prevalence of MetS was detected to be significantly higher in patients with PHPT than in controls $(p<0.02)$. This higher prevalence was more prominent among patients with asymptomatic PHPT. In multivariate analysis performed on healthy individuals and patients with the same age, gender and BMI values, asymptomatic PHPT with low risk for end organ damage was found to be a determinant of MetS. In a study by Ayturk et al. (12), homeostasis model assessment index was detected to be significantly higher in asymptomatic hyperparathyroidism group than in control group ( $p=0.035)$, while the prevalence of pre-diabetes, impaired fasting glucose and newly diagnosed diabetes mellitus were similar in both groups. During the 18-month follow-up of these patients, no changes were detected in insulin sensitivity and glucose metabolism disorders. In the evaluation of the patients in our study group, the prevalence of MetS in asymptomatic and symptomatic PHPT groups were $35 \%$ and $43.1 \%$, respectively, which showed no statistically significant difference.

Some epidemiological studies showed increased mortality and morbidity rate in patients with PHPT $(13,14)$. Although our study revealed that the prevalence of MetS in patients with PHPT was similar to that in the general population with the same age, some syndrome abnormalities such as hypertension, increased waist circumference and lipid profile disorders that may cause increased cardiovascular morbidity and mortality were more common in these patients. In addition, Jeong et al. (15) found that MetS was a strong and independent risk factor for kidney stone formation. Similarly, the prevalence of urinary stones was higher among our patients with MetS.

\section{Conclusion}

Our study has some limitations in some aspects; the first one is being its retrospective nature. Secondly, we were unable to obtain all laboratory data of patients regarding MetS (insulin resistance, hs-CRP, uric acid etc.), for this reason, these data were not evaluated. In line with these findings, we suggest that MetS and related abnormalities should be considered in follow-up and treatment of patients with PHPT.

\section{Ethics}

Ethics Committee Approval: Ethics committee approval was received for this study from the Ethics Committee of University (Approval Date: 27/03/2013, Approval Number: 07/01).

Peer-review: Internally peer-reviewed.

\section{Author Contributions}

Surgical and Medical Practices: H.Ç. Concept: S.G., A.A.T. Design: G.T.Ç. Data Collection or Processing: H.Ç., N.S.A. Analysis or Interpretation: N.S. Literature Search: S.A., N.S.A. Writing: S.G., M.Ç.

Conflict of Interest: No conflict of interest was declared by the authors.

Financial Disclosure: The authors declared that this study has received no financial support.

\section{References}

1. Tassone F, Gianotti L, Baffoni C, et al. Prevalence and characteristics of metabolic syndrome in primary hyperparathyroidism. J Endocrinol Invest 2012;35:841-6.

2. Khan AA, Bilezikian JP, Potts JT Jr. Guest Editors for the Third International Workshop on Asymptomatic Primary Hyperparathyroidism. The diagnosis and management of asymptomatic primary hyperparathyroidism revisited. J Clin Endocrinol Metab 2009;94:333-4.

3. Mendoza-Zubieta V, Gonzalez-Villaseior GA, Vargas-Ortega G, et al. High prevalence of metabolic syndrome in a group of adult patients with primary hyperparathyroidism (PHPT). BMC Endocr Disord 2015;15:16.

4. American Diabetes Association. Standards of medical care in diabetes. Diabetes Care 2014;37:14-80.

5. Whitworth JA. World Health Organization, International Society of Hypertension Writing Group. 2003 World Health Organization (WHO) / International Society of Hypertension 
(ISH) statement on management of hypertension. J Hypertension 2003;21:1983-92.

6. Levesque J, Lamarche B. The metabolic syndrome: definitions, prevalence and management. J Nutrigenet Nutrigenomics 2008;1:100-8.

7. Onat $A$, Yüksel M, Köroğlu B, et al. Turkish Adult Risk Factor Study survey 2012: overall and coronary mortality and trends in the prevalence of metabolic syndrome. Turk Kardiyol Dern Ars 2013;41:373-8.

8. Procopio M, Barale M, Bertaina S, et al. Cardiovascular risk and metabolic syndrome in primary hyperparathyroidism and their correlation to different clinical forms. Endocrine 2014;47:581-9.

9. Delfini E, Petramala L, Caliumi C. Circulating leptin and adiponectin levels in patients with primary hyperparathyroidism. Metabolism 2007;56:30-6.

10. Luboshitzky R, Chertok-Schaham Y, Lavi I, Ishay A. Cardiovascular risk factors in primary hyperparathyroidism. J Endocrinol Invest 2009;32:317-21.
11. Rojas R, Aguilar-Salinas CA, Jiménez-Corona A, et al. Metabolic syndrome in Mexican adults: result from the National Health and Nutrition Survey 2006. Salud Publica Mex 2010;52(Suppl 1):S11-8.

12. Ayturk S, Gursoy A, Bascil Tutuncu N, Ertugrul DT, Guvener Demirag $\mathrm{N}$. Changes in insulin sensitivity and glucose and bone metabolism over time in patients with asymptomatic primary hyperparathyroidism. J Clin Endocrinol Metab 2006;91:4260-3.

13. Lind L, Jakobsson S, Lithell $H$, Wengle $B$, Ljunghall S. Relation of serum calcium concentration to metabolic risk factors for cardiovascular disease. BMJ 1988;297:960-3.

14. Ahlström T, Hagström E, Larsson A, Rudberg C, Lind L, Hellman P. Correlation between plasma calcium, parathyroid hormone (PTH) and the metabolic syndrome (MetS) in a community-based cohort of men and women. Clin Endocrinol (Oxf) 2009;71:673-8.

15. Jeong IG, Kang T, Bang JK, et al. Association between metabolic syndrome and the presence of kidney stones in a screened population. Am J Kidney Dis 2011;58:383-8. 